\title{
Reconstructing long-term gully dynamics in Mediterranean agricultural areas
}

\author{
Antonio Hayas ${ }^{1}$, Tom Vanwalleghem ${ }^{1}$, Ana Laguna ${ }^{2}$, Adolfo Peña ${ }^{3}$, and Juan V. Giráldez ${ }^{1,4}$ \\ ${ }^{1}$ University of Cordoba, Dept. of Agronomy, da Vinci Bldg., Cra Madrid km 396, 14071 Córdoba, Spain \\ ${ }^{2}$ University of Cordoba, Dept. of Applied Physics, Einstein Bldg., Córdoba, Spain \\ ${ }^{3}$ University of Cordoba, Dept. of Rural Engineering, da Vinci Bldg., Córdoba, Spain \\ ${ }^{4}$ Institute for Sustainable Agriculture, CSIC, Dept. of Agronomy, Alameda del Obispo, 14080 Córdoba, Spain \\ Correspondence to: Antonio Hayas (z22haloa@uco.es)
}

Received: 16 May 2016 - Published in Hydrol. Earth Syst. Sci. Discuss.: 15 June 2016

Revised: 7 November 2016 - Accepted: 20 November 2016 - Published: 11 January 2017

\begin{abstract}
Gully erosion is an important erosive process in Mediterranean basins. However, the long-term dynamics of gully networks and the variations in sediment production in gullies are not well known. Available studies are often conducted only over a few years, while many gully networks form, grow, and change in response to environmental and land use or management changes over a long period. In order to clarify the effect of these changes, it is important to analyse the evolution of the gully network with a high temporal resolution. This study aims at analysing gully morphodynamics over a long timescale (1956-2013) in a large Mediterranean area in order to quantify gully erosion processes and their contribution to overall sediment dynamics.

A gully network of $20 \mathrm{~km}^{2}$ located in southwestern Spain has been analysed using a sequence of 10 aerial photographs in the period 1956-2013. The extension of the gully network both increased and decreased in the study period. Gully drainage density varied between $1.93 \mathrm{~km} \mathrm{~km}^{-2}$ in 1956 , a minimum of $1.37 \mathrm{~km} \mathrm{~km}^{-2}$ in 1980 , and a maximum of $5.40 \mathrm{~km} \mathrm{~km}^{-2}$ in 2013. The main controlling factor of gully activity appeared to be rainfall. Land use changes were found to have only a secondary effect. A new Monte Carlo-based approach was proposed to reconstruct gully erosion rates from orthophotos. Gully erosion rates were found to be relatively stable between 1956 and 2009, with a mean value of $11.2 \mathrm{tha}^{-1} \mathrm{yr}^{-1}$. In the period 2009-2011, characterized by severe winter rainfalls, this value increased significantly to $591 \mathrm{tha}^{-1} \mathrm{yr}^{-1}$. These results show that gully erosion rates are highly variable and that a simple interpolation between the starting and ending dates greatly underestimates gully
\end{abstract}

contribution during certain years, such as, for example, between 2009 and 2011. This illustrates the importance of the methodology applied using a high temporal resolution of orthophotos.

\section{Introduction}

Understanding gully erosion dynamics under changing land use and climate conditions is essential for soil and water conservation. Erosion is one of the most significant threats to soils and sustainable agriculture worldwide (Amundson et al., 2015). To satisfy long-term food production and food safety, soil erosion rates should be drastically reduced to the level of soil formation rates. Additionally, sediment dispersion induces environmental pollution, with severe downstream problems for infrastructure. Soil erosion is a major factor in the anthropogenic perturbation of the global carbon cycle (Regnier et al., 2013). Given its importance, much research effort has gone into characterizing and modelling erosion rates in order to identify key problem areas and propose management solutions. Recently, a European-wide effort was conducted to improve the quantification of water erosion either with RUSLE (Panagos et al., 2015) or with similar models (Quinton et al., 2010; Van Oost et al., 2007). Nevertheless, such models represent a minor part of the water erosion processes by not considering the contribution of gullies. Poesen et al. (2002) concluded that gully erosion could be the source of up to $83 \%$ of sediment yield in Mediterranean areas. Recent efforts to measure gullies in detail confirm these 
numbers. For instance, Castillo (2012) estimated the range of gully erosion rates in a set of cultivated catchments in Cordoba as being 37 to $250 \mathrm{tha}^{-1} \mathrm{yr}^{-1}$.

Most erosion models for gully erosion focus on modelling headcut growth. Examples are REGEM and its adaptation TIEGEM, both used in the Annualized AGricultural Non-Point Source model (AnnAGNPS; Gordon et al., 2007; Taguas et al., 2012), CHILD (Flores-Cervantes et al., 2006; Campo-Bescós et al., 2013), or the headcut growth model by Rengers and Tucker (2014). Kirkby and Bracken (2009) presented an areal gully growth model that showed how the ratio of channel versus sidewall processes is a key determinant in its evolution. In contrast, Dabney et al. (2015) modelled gully erosion rates by shear stress by inserting a new Ephemeral Gully Erosion Estimator (EphGEE), included in a new version of RUSLE2, into a small agricultural watershed in Iowa. More mathematically based models seek general laws controlling areal gully growth and ramification (e.g. Devauchelle et al., 2012). In general however, there is an important lack of suitable field data for understanding and modelling longterm gully evolution.

Different methodologies, apart from traditional field measurements with total stations, laser profilemeters, and poles (Castillo et al., 2012), have been proposed and successfully applied to estimate gully volumes. For instance, at the individual gully scale, 3-D reconstruction from high-resolution aerial photography and digital photogrammetry has been widely applied (e.g. Marzolff and Poesen, 2009). Recently, terrestrial imagery modelling and structures from motionmulti-view stereo (SfM-MVS) procedures have been used to determine gully volumes (Gómez-Gutiérrez et al., 2014; Frankl et al., 2015; Castillo et al., 2015). Terrestrial lidar has been applied to measure rills or gullies at both laboratory and plot scale (Vinci et al., 2016; Momm et al., 2011, 2012). Nevertheless, at the catchment scale, the number of studies is limited. At this scale, most studies focus on the areal extension of gully networks, using aerial photos or other remotely sensed imagery. Few studies report gully volumes due to the inherent difficulties in determining depths for the whole gully network. Nachtergaele and Poesen (1999) determined gully length from aerial photos and, by using additional field measurements, they established a mean cross section to calculate volumes of small ephemeral gullies in the Belgian loess belt. Martínez-Casasnovas (2000) mapped and quantified the erosion produced in gully systems of big dimensions by processing multitemporal orthophotograms and digital elevation models (DEMs) in a geographic information system (GIS) for a $25 \mathrm{~km}^{2}$ catchment located in north-eastern Spain. Frankl et al. (2011) used sequential photographs to link longterm gully and river dynamics to environmental change in northern Ethiopia. More recently, Peter et al. (2014) used UAVs and photogrammetric analysis to quantify gully erosion, albeit at a local scale in the Souss Basin (Morocco).

Due to the recent nature of most of these field studies on gully erosion, their temporal coverage is limited to a few years at best. More recent studies usually focus on one specific moment in time, where the gully system is visited and measured once or during a couple of years. This implies that no dynamic behaviour of the gully system can be described adequately and that it is difficult to single out the controlling processes. Growth of gully systems in the Belgian loess belt was shown by Vanwalleghem et al. (2005) to be a highly non-linear process, with a rapid initial growth followed by a stabilization phase. Under different climates, where rainfall is less uniform and much more concentrated, such non-linear gully dynamics can be expected to be accentuated. It could therefore happen that a single measurement of a gully volume that has been growing for several decades does not offer a good estimate of yearly growth rates. Gully growth can be expected to be much greater during specific years compared to the long-term mean. Any model efforts will therefore need experimental data collected with a high temporal resolution.

Over such longer timescales, exceeding several decades, few experimental data are available. Over timescales of up to several centuries, different studies indicate that gully erosion is not a new process. In northern and central Europe, gullies have been dated between Early Bronze Age and Late Medieval times (Vanwalleghem et al., 2006). In the western Mediterranean, with a long history of land use, such historical studies are rare however (Dotterweich, 2013). Over the medium term, of several decades, available studies point to an important dynamic of ephemeral gullies, with erosion phases and infilling ones. These can be due to normal tillage operations for small, ephemeral gullies; deliberately done by farmers in case of larger gullies; or during land use change phases, in which farmers erase such topographic features by tillage, as has been supported by field evidence. Gordon et al. (2008) showed by simulations using the REGEM model that those erosion and infilling cycles could produce up to double the amount of sediment as when gullies were left to erode naturally. Each infilling phase prepares sediment for the next important storm event. Field data for this timescale are rare and generally come from the analysis of historical aerial photos. Frankl et al. (2013) quantified the evolution of a permanent gully network in Ethiopia using long-term historical aerial photos over the period 1963-2010 for an area of $123 \mathrm{~km}^{2}$. After an initial stability phase, they identified a peak erosion period in 1994, after which the system stabilized again. These results stress the importance of frequent temporal observations. Saxton et al. (2012) analysed multitemporal aerial photographs between 1951 and 2006 to derive historical gully erosion rates in terms of surface growth per year in three catchments in south-eastern Queensland in Australia. They associated the gully initiation with post-European settlement land use practice and above average rainfall and runoff. Also, Shellberg et al. (2016) observed an increase in the gully erosion by the changes in the land use produced by post-European settlement in the Mitchell River fluvial megafan (Queensland, Australia). This relationship between pioneers and gully erosion was previously sug- 
Table 1. Orthophoto dataset properties.

\begin{tabular}{lcccccccccc}
\hline Capture year & 1956 & 1980 & 1984 & 1999 & 2001 & 2005 & 2007 & 2009 & 2011 & 2013 \\
Resolution, $\mathrm{m}$ & 1.0 & 0.5 & 1.0 & 1.0 & 0.5 & 0.5 & 0.5 & 0.5 & 0.5 & 0.5 \\
Colour & $\mathrm{b} / \mathrm{w}$ & $\mathrm{b} / \mathrm{w}$ & $\mathrm{b} / \mathrm{w}$ & $\mathrm{b} / \mathrm{w}$ & $\mathrm{b} / \mathrm{w}$ & $\mathrm{col}$. & $\mathrm{col}$. & $\mathrm{col}$. & $\mathrm{col}$. & $\mathrm{col}$. \\
\hline
\end{tabular}

b/w: black and white; col.: colour; all restitution scales are $1: 10000$, except 1980 with scale $1: 5000$.

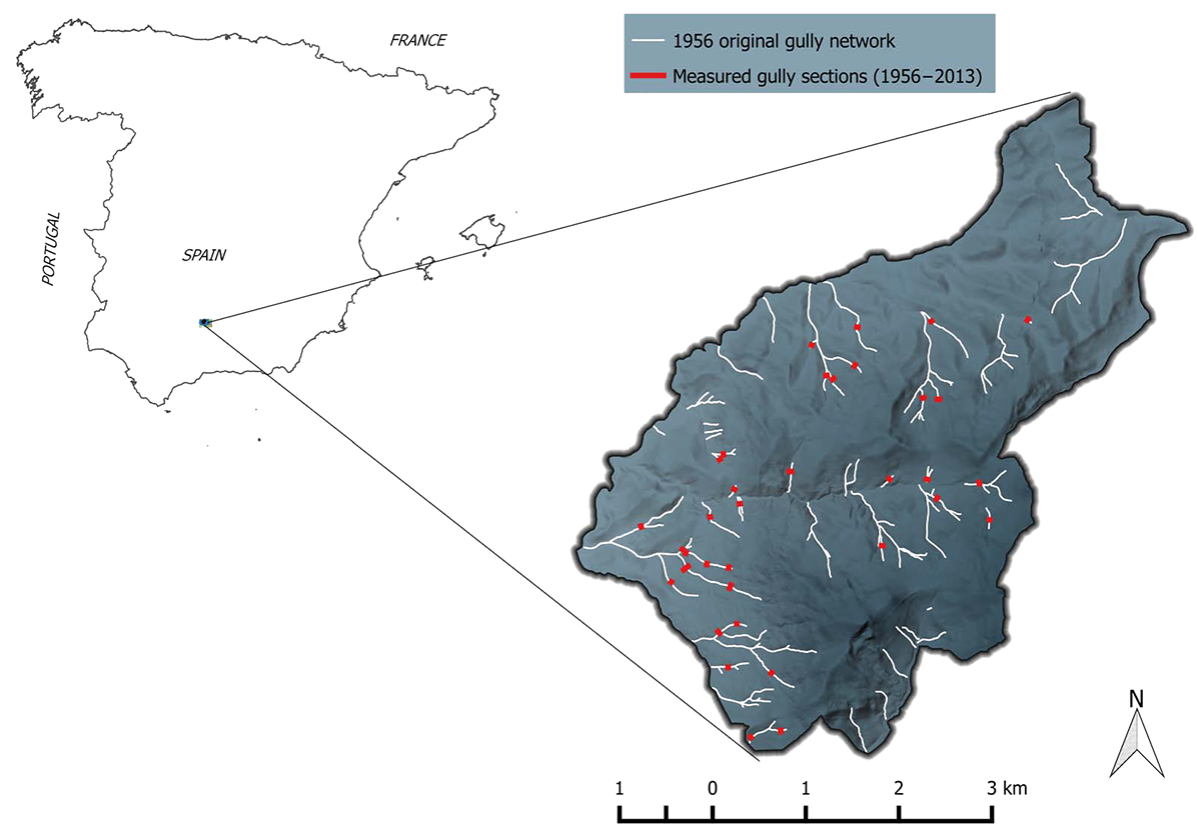

Figure 1. Site location with details of the original gully network and measured gully sections.

gested by Leopold (1991) in the US. Other methods have been tested, such as using local farmer knowledge on gully morphology (Nyssen et al., 2006; Tebebu et al., 2010) or multi-temporal oblique photography of gully cross sections (Frankl et al., 2011), but the uncertainty in the results is generally too great to allow a quantitative analysis of controlling climate or land use factors.

The objective of this study was, then, to quantify the erosion and infilling dynamics of a gully network in a typical agricultural area of southwestern Spain from historical air photos between 1956 and 2013. A new method is presented that not only allows one to determine the evolution of gully length, but also, by using Monte Carlo analysis to generate gully width and depth, to calculate the volume of gully erosion and infilling and to constrain uncertainty. Moreover, the controls in terms of land use and rainfall variability are analysed and the importance of these results for the regional sediment budget assessed.

\section{Materials and methods}

\subsection{Study site}

The study area is located between 37.74 and $37.81^{\circ} \mathrm{N}$, 4.36 and $4.43^{\circ} \mathrm{W}$, in the western Campiña of the Guadalquivir basin in southwestern Spain (Fig. 1), and comprises an area of $20.6 \mathrm{~km}^{2}$. The studied gully network drains towards a series of small ephemeral rivers (Arroyo de Garuñana, Arroyo del Cuadrado, Arroyo del Pozo Muerto, Arroyo de las Monjas, and Arroyo del Barranco), which all drain to the Guadajoz, a tributary of the Guadalquivir River. Although the limits between rills, gullies, and larger ephemeral river channels are subject to discussion in the scientific community, this ephemeral river network was not included in the analysis, as it is indicated on the topographical maps and is assumed to be stable. The observed gullies can be considered to be mostly permanent (Fig. 2), although some ephemeral ones are included as long as they have a width equal to or higher than the resolution of the orthophotos that were used, ranging between 0.5 and $1.0 \mathrm{~m}$ (Table 1).

Gentle hills prevail in the study area, except for the south and the central east, where steeper ones exist (up to $32 \%$ ). Altitudes range from 233 to $558 \mathrm{~m}$ high and mean slopes 


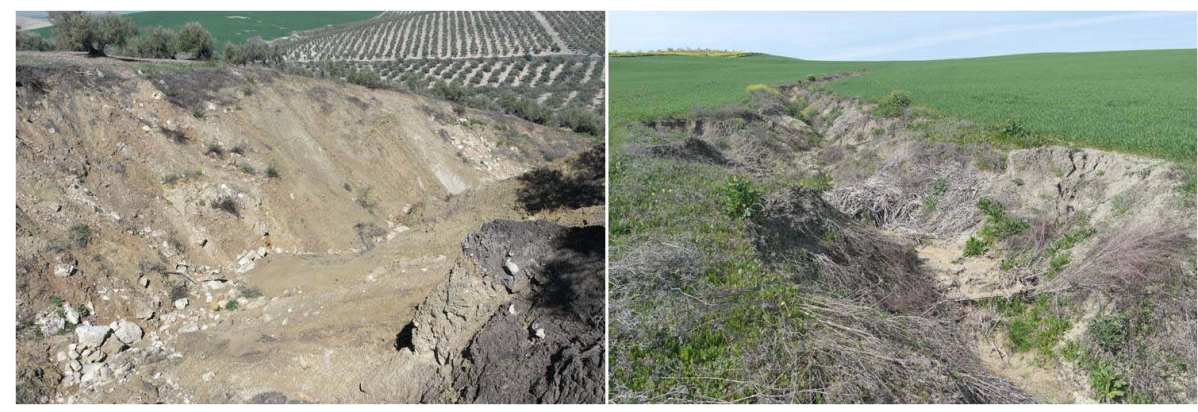

Figure 2. Typical gullies in olive orchards (left panel) and in herbaceous crops (right panel) in the study zone.

are $13 \%$. The soils in the area are dominated by Vertisols, formed mainly in marls, and calcareous sandstones deposited during the Miopliocene.

Currently the dominating land uses are olive orchards and herbaceous crops covering almost the whole area, except some $5 \%$ of the surface area occupied by grassland. Mean annual precipitation varies between 500 and $600 \mathrm{~mm}$ (Córdoba Airport station and Baena RIA station). The distribution of the precipitation shows a marked dry season between June and September, while the main wet period occurs from October to May.

\subsection{Rainfall characterization}

Characterization of the rainfall regime was performed from daily rainfall collected in the periods $1956-2013$ at Castro del Río weather station $\left(37.69^{\circ} \mathrm{N}, 4.47^{\circ} \mathrm{W}\right)$, belonging to the Spanish National Meteorological Agency (AEMET). Isolated data gaps of between 1970 and 1971 were filled from the data recorded at Cañete de las Torres weather station $\left(37.83^{\circ} \mathrm{N}, 4.36^{\circ} \mathrm{W}\right.$, Phytosanitary Warnings Network of Andalusia, RAIF) and Córdoba Airport weather station $\left(37.84^{\circ} \mathrm{N}, 4.84^{\circ} \mathrm{W}\right.$, AEMET). Anomalies in annual rainfall were evaluated by means of normalization, through average and standard deviation of annual rainfall for a 57year period (1956-2013), following Martínez-Casasnovas et al. (2003). Values falling outside the interval $R_{\text {mean }}$ (average rainfall) $\pm \mathrm{SD}$ (standard deviation), which correspond to the normalized values $>1$ and $<-1$, were considered to be anomalies.

The frequency distribution of daily rainfall above a threshold value of $13 \mathrm{~mm}$ was analysed, considering this as the minimum rainfall that produces erosive effects as proposed by Wischmeier and Smith (1978) and Renard et al. (1997). In addition, the frequency distribution of records above the average daily rainfall event plus the standard deviation were analysed as well, assuming that these events represent the extreme rainfall events within the study period.

\subsection{Photointerpretation process}

Analysis of gully evolution and land use change was conducted by photointerpretation based on a dataset of aerial orthophotos of different years from 1956 to 2013. Performance characteristics of the orthophoto dataset are summarized in Table 1 . The working scale in the photointerpretation processes was established at 1:5000 for the whole dataset.

\subsubsection{Land use}

Land use in the study area for 2001, 2005, 2009, 2011, and 2013 was derived from the respective orthophotos, while for the rest of the years $(1956,1980,1984,1999,2003$, and 2007) existing Maps of the Land Use and Vegetation Cover of Andalusia (Red de Información Ambiental de Andalucía, REDIAM) were employed. Different land uses present in the area were simplified to three classes as shown in Table 2.

\subsubsection{Gully network length}

Gully length was obtained by digitizing the extension of the network for each available year (Fig. 3), distinguishing between newly incised and infilling stretches. The gully network was decomposed into $m_{y}$ segments, where subscript $y$ indicates the year. Each segment comprises the length between consecutive junctions (Fig. 4). Due to changes in the drainage network during the study period, the number of segments ranged between 108 in 1980 and 940 in 2013. The total length of the drainage network for a given year, $L_{y}$, was calculated as the sum of the lengths of individual segments, $l_{y, i}$,

$L_{y}=\sum_{i=1}^{m_{y}} l_{y, i}$,

with $m_{y}$ equal to the total number of individual segments of the gully network for each digitalized year. 

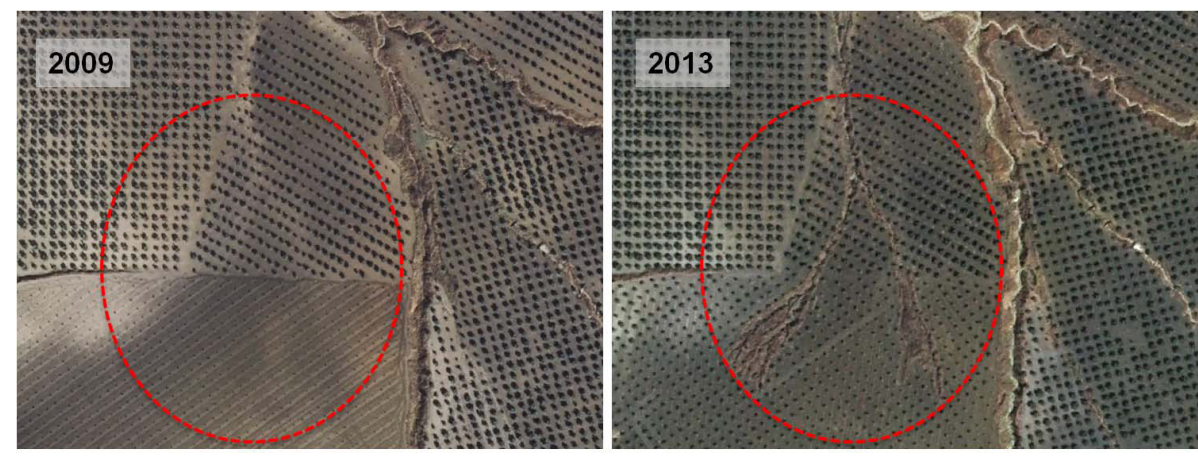

Figure 3. Example of orthophotos showing gully incision between 2009 and 2013 from an old (left panel) into a new plantation (right panel).

Table 2. Correspondences of the simplified land use classes adopted in this study with the Map of the Land Use and Vegetation Cover of Andalusia (MUCVA, REDIAM).

\begin{tabular}{ll}
\hline MUCVA classes & Simplified classes \\
\hline $\begin{array}{l}\text { Herbaceous crops with scattered trees } \\
\text { Non-irrigated herbaceous crops } \\
\text { Irrigated herbaceous crops }\end{array}$ & Herbaceous crops \\
\hline Non-irrigated tree crops: olive orchards & Olive orchards \\
\hline $\begin{array}{l}\text { Pasture } \\
\text { Dense scrubland }\end{array}$ & Other land use \\
Streams and natural watercourses & \\
\hline Agricultural buildings and farms & \\
\hline
\end{tabular}

\subsubsection{Gully network width}

In order to measure gully width representatively, 35 stretches were selected from the earliest digitalized gully network of 1956 (Fig. 1), covering a wide range of widths. Gully width was measured at the same locations on later orthophotos, allowing the evaluation of the widening process during the complete study period.

\subsection{Field campaign}

During 2013 and 2014, several field campaigns were conducted to measure current gully widths and depths with measuring tape and a clinometer (Suunto PM-5/360 PC). Gully top width and depth were measured at 27 representative sections that were located as close as possible to the 35 sections used in the photointerpretation. These representative sections covered the entire range of width and depth variability, including different landscape positions, from upstream close to the divide to the junction with the stream network, and both in gullies on herbaceous crops and under olive trees. This method of combining photointerpretation with field measurements of gully morphology is similar to Nachtergaele and Poesen (1999).

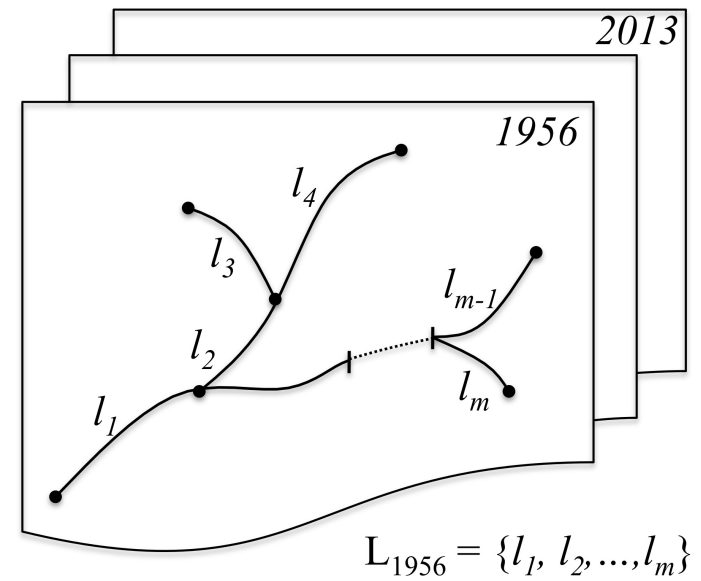

Figure 4. Illustration of the decomposition of the gully network into individual segments for the Monte Carlo-based simulation process.

\subsection{Monte Carlo-based simulations}

Although gully length for the different years between 1956 and 2013 could be determined directly from observations using the available air photographs, determination of the gully volume was not so straightforward. As we used freely available orthophotos, it was only possible to measure the size of the gullies in two dimensions and no measure of depth was readily available. Also, observations of gully width for each year were limited to the representative sections measured on the orthophotos of that particular year, and therefore included a term of uncertainty as the real population mean remained unknown.

Estimation of overall gully network volume for each year, $\bar{V}_{y}$, was therefore tackled by conducting a Monte Carlo simulation in which a volume and an associated uncertainty were calculated for every single gully segment, $l_{y, i}$, described in Sect. 2.3.2 (Fig. 4).

For each year, $y$, a set of $n=1000$ estimated cross area sections, $S_{y, i}=\left\{s_{y, i, j}, j=1, \ldots, n\right\}$ for every single segment, $l_{y, i}$, were generated as shown in Fig. 5, which required 


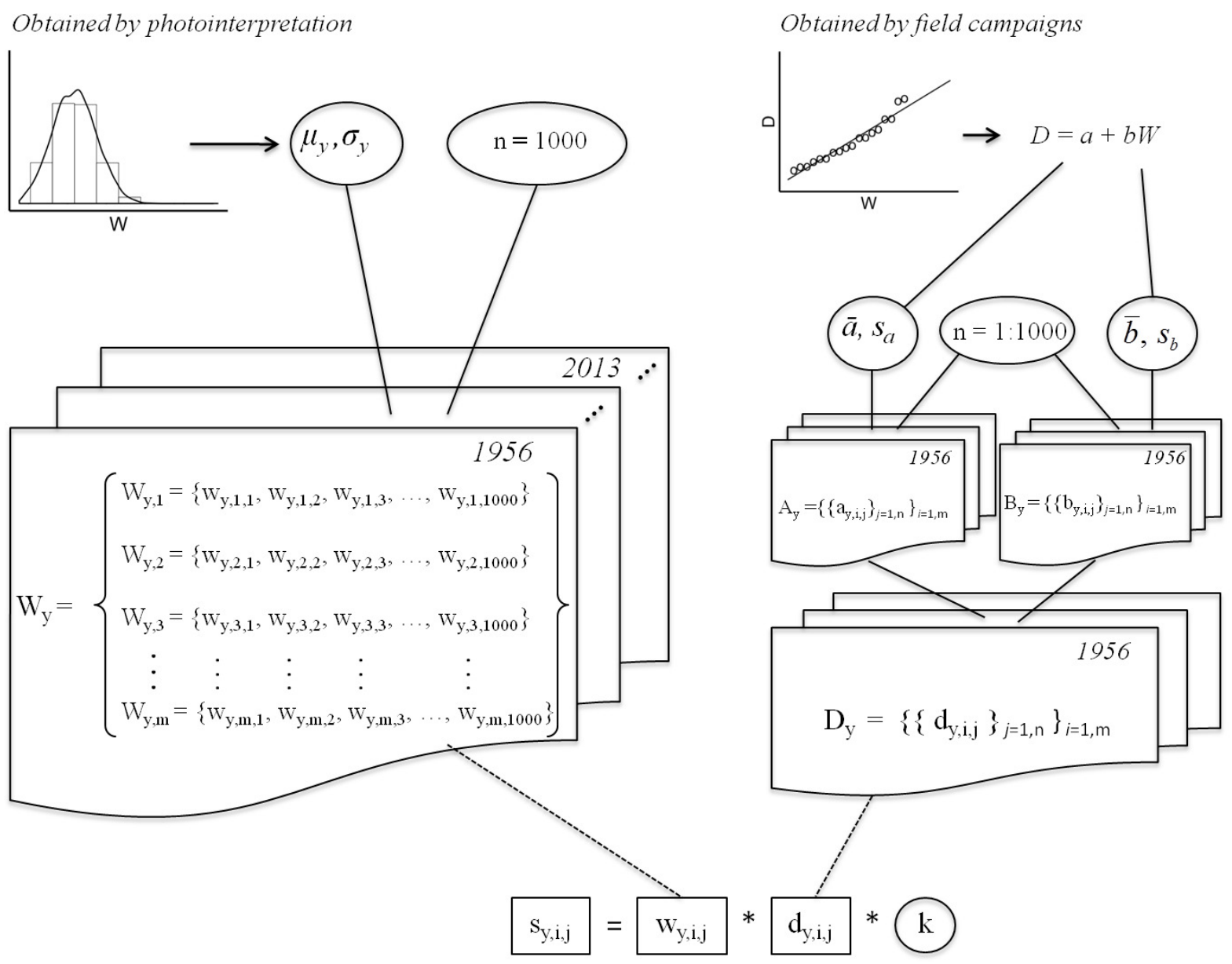

Figure 5. Conceptual scheme of the Monte Carlo simulation processes conducted to generate gully widths $\left(w_{y, i, j}\right.$ : single simulated width for a given segment and year; $W_{y, i}$ : set of 1000 simulated widths for a given segment and year) and depths $\left(d_{y, i, j}\right.$ : single simulated depth for a given segment and year; $D_{y, i}$ : set of 1000 simulated depths for a given segment and year) and to calculate the cross section $\left(S_{y, i}\right)$ for each gully segment and year. $k$ is a shape factor for the gully cross section, $m$ is the number of gully segments, $n$ is the number of simulations, and $a$ and $b$ are fitted linear regression coefficients of the depth-width relation, with respective means $(\bar{a}, \bar{b})$ and standard deviations $\left(s_{a}, s_{b}\right)$.

the generation of sets of width and depth values for each year. Each generated section is calculated as

$s_{y, i, j}=k w_{y, i, j} d_{y, i, j}$

where $k$ is a shape factor, and $w_{y, i, j}$ and $d_{y, i, j}$ the simulated gully width and depth, respectively. Field observations suggested that a triangular section is a reasonable approximation of most gully sections, so a shape factor $k=0.5$ was adopted in order to compute the simulated sections.

To generate a representative measure of gully width, first of all, the gully width distribution measured for each year by photointerpretation at the representative sections was fitted to different probability distribution functions (normal or Gaussian, gamma, lognormal, exponential, and Weibull) using the maximum likelihood method. Next, goodness of fit was evaluated for these different distributions by means of the Kolmogorov-Smirnov statistics. Finally, the best overall fitting theoretical probability distribution was selected to obtain the necessary parameters $\left(\mu_{y}, \sigma_{y}\right)$ to generate $n$ random simulations of representative gully widths for any particular year.

The estimation of gully depth for each year was based on the field data gathered in 2013-2014. In order to estimate depth for previous years, firstly a width-depth relationship was estimated by linear regression analysis from the collected field data. Such a relationship could only be established for the present-day situation. Uncertainty in this linear width-depth relation was then taken into account by computing the estimated intercept, slope, and their respective standard deviations $\left(a, b, s_{a}, s_{b}\right)$. Assuming a normal distribution, a set of 1000 slope and intercept pairs were simulated. Depths for unique segments $\left(D_{y, i}\right)$ were then derived from simulated widths and slope-intercept pairs. 
Table 3. Land use, rainfall indicators, and gully growth. $f_{\mathrm{h}}$ and $f_{\mathrm{o}}$ : fractions of surface dedicated to herbaceous and olive crops, in the first year of each period. nle: number of $24 \mathrm{~h}$ rainfall events per year higher than $13 \mathrm{~mm}$; nleo: number of $24 \mathrm{~h}$ rainfall events per year over the average $24 \mathrm{~h}$ rainfall plus the standard deviation; $R_{\max }$ : highest daily rain depth registered within the period; MAR: mean annual rainfall in the period. $\Delta L$ : total, and $\Delta L / \Delta t$, partial increase in gully length, and $\mathrm{GH}$ : gully headcut growth, averaged over the area.

\begin{tabular}{|c|c|c|c|c|c|c|c|c|c|c|}
\hline \multirow[b]{2}{*}{ Period } & \multirow[b]{2}{*}{$\begin{array}{r}\Delta t \\
\mathrm{yr}\end{array}$} & \multicolumn{2}{|c|}{ Land use } & \multicolumn{4}{|c|}{ Rainfall } & \multicolumn{3}{|c|}{ Gully growth } \\
\hline & & $f_{\mathrm{h}}$ & $f_{\mathrm{o}}$ & nle & nleo & $R_{\max }$ & MAR & $\begin{array}{l}\Delta L \\
\mathrm{~km}\end{array}$ & $\begin{array}{r}\Delta L / \Delta t \\
\mathrm{~km} \mathrm{yr}^{-1}\end{array}$ & $\mathrm{~m} \mathrm{ha}^{-1} \mathrm{yr}^{\mathrm{GH}}$ \\
\hline 1956 & & .85 & .13 & & & & & & & \\
\hline 1956-1980 & 24 & .74 & .25 & 12.9 & 6.8 & 70.0 & 494 & -7.37 & -0.31 & -0.15 \\
\hline 1980-1984 & 4 & .74 & .25 & 9.5 & 5.0 & 86.0 & 377 & 10.58 & 2.65 & 1.25 \\
\hline 1984-1999 & 15 & .52 & .48 & 17.1 & 10.5 & 140.0 & 677 & 29.67 & 1.98 & 0.94 \\
\hline 1999-2001 & 2 & .50 & .50 & 11.0 & 5.0 & 70.0 & 501 & -3.06 & -1.53 & -0.72 \\
\hline 2001-2005 & 4 & .49 & .50 & 11.8 & 4.5 & 41.0 & 438 & -3.49 & -0.87 & -0.41 \\
\hline 2005-2007 & 2 & .41 & .59 & 13.0 & 5.5 & 46.0 & 477 & 1.36 & 0.68 & 0.32 \\
\hline 2007-2009 & 2 & .39 & .61 & 11.5 & 5.5 & 126.0 & 545 & -5.48 & -2.74 & -1.30 \\
\hline 2009-2011 & 2 & .38 & .61 & 27.5 & 13.0 & 68.5 & 917 & 48.77 & 24.39 & 11.54 \\
\hline 2011-2013 & 2 & .36 & .63 & 12.5 & 6.0 & 57.2 & 492 & 2.36 & 1.18 & 0.56 \\
\hline
\end{tabular}

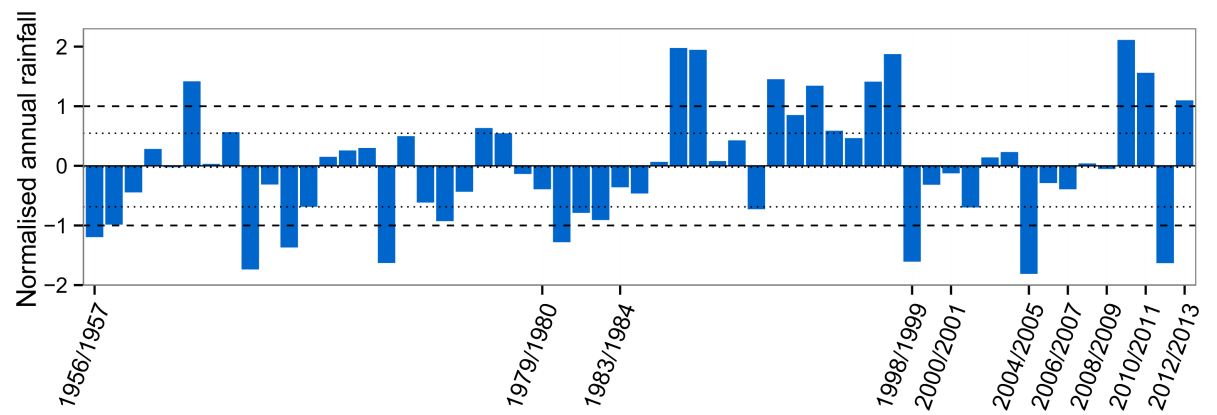

Figure 6. Standardized annual rainfall in the period 1956-2013.

Finally, a set of $n$ simulated volumes $V_{y, i}=\left\{v_{y, i, j}\right.$, $j=1, \ldots, n\}$ was calculated for each year and segment by multiplying individual measured lengths by the simulated sections (Fig. 5):

$v_{y, i, j}=s_{y, i, j} l_{y, i}$.

A set of $n$ different simulated volumes of the complete gully network for a particular year $V_{y}$ was eventually calculated as the sum of volumes of single segments $v_{y, i, j}$ :

$V_{y}=\left\{v_{y, i, j}, j=1, \ldots, n\right\}$

and

$v_{y, j}=\sum_{i=1}^{m_{y}} v_{y, i, j}$.

Finally, the average volume of the total gully network for a given year, $\bar{V}_{y}$, was computed as

$\bar{V}_{y}=\frac{1}{n} \sum_{j=1}^{n} v_{y, j}$.
Erosion rates were then obtained from the difference between pairs of simulated volumes on consecutive dates divided by the duration of the period.

\section{Results}

\subsection{Rainfall characteristics during the study period}

The annual rainfall depths in the analysed period ranged between $180 \mathrm{~mm}$ in the hydrological years $2004 / 2005$ and $973 \mathrm{~mm}$ in 2009/2010, with an average value of $546 \mathrm{~mm}$ (Table 3). Figure 6 shows standardized annual rainfall between 1956 and 2013 and the anomalies of annual rainfall. Annual rainfalls over the 75 th percentile $(656 \mathrm{~mm})$ were recorded on 15 occasions, of which 10 surpassed the average annual rainfall plus the standard deviation $(748 \mathrm{~mm})$. Among the lapses between the aerial orthophoto dataset, the periods 1984-1999 and 2009-2011 concentrated the highest number of positive extreme annual rainfall events. In 198419998 out of 15 records were over the 75th percentile, and 6 of them were considered to be anomalies since they were higher than the average annual rainfall plus the standard devi- 


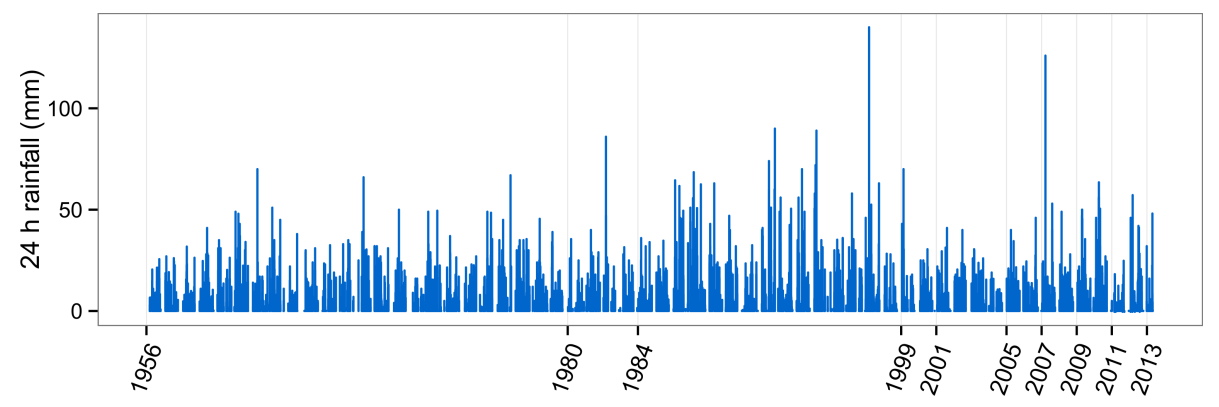

Figure 7. Daily rainfall recorded in the period 1956-2013.

ation. In the period 2009-2011, in both years, larger amounts of annual rainfall than the standard deviation were recorded, and can thus be considered an anomalously severe rainy period.

Figure 7 shows the distribution of the 3698 daily rainfall events recorded during the study period. Daily rainfall events $\left(R_{24}\right)$ higher than $13 \mathrm{~mm}$ accounted for $21.7 \%$ of the total recorded. Among the different periods the highest proportion of $R_{24}>13 \mathrm{~mm}$ was recorded in 2009-2011 (27.5 events per year, Table 3 ), whereas the average proportion was $13.9 R_{24}$ events $>13 \mathrm{~mm}$ per year. Rain depths higher than the average value $(8.4 \mathrm{~mm})$ plus the standard deviation $(10.8 \mathrm{~mm})$ were considered extraordinary events, which were concentrated in a higher proportion in the periods 1984-1999 (10.5 records per year) and 2009-2011 (13 records per year) (Table 3 ). Maximum daily rainfalls were recorded in the hydrological years 1997/1998 (140 mm) and 2007/2008 (126 mm), with an average value of $48.68 \mathrm{~mm}$ for the entire period.

\subsection{Land use change}

Land use experienced a progressive conversion from herbaceous crops to olive orchards as shown in Fig. 8. In the study period, olive orchards grew from 13 to $63 \%$ of the total catchment area at the same as time herbaceous crops decreased from 85 to $35 \%$ of the total catchment area. The main land use change occurred between 1984 and 1999, when the olive orchards went from occupying 25 to $48 \%$ of the total catchment area. The highest rates of change however were observed in the period 2005-2007, with a more than $4 \%$ rate of annual land use change from herbaceous crops to olive orchards.

\subsection{Gully network length dynamics}

Figure 9 shows the evolution of the gully network derived by photointerpretation between 1956 and 2013, with drainage density included. From 1956 to 2013 the gully network increased not only in length, but also in number of branches. Further analysis on the length and area ratio showed that the drainage density had grown from 17.2 to $53.3 \mathrm{~m} \mathrm{ha}^{-1}$.

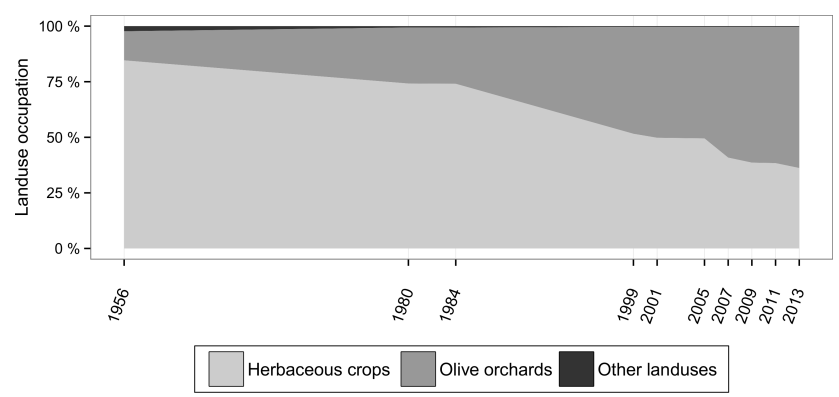

Figure 8. Land use changes in the period 1956-2013.

There seems to be a greater increase in the south compared to the north, which suggests a more stable condition in the latter. In most of the analysed period, the variations in drainage density were small. However, there were two significant periods when the increase was very high and that account for the main increases in the overall value. From 1984 to 1999 and 2009 to 2011 there was an increment of 14.6 and $23.6 \mathrm{~m} \mathrm{ha}^{-1}$, respectively, which accounted for $84 \%$ of the total drainage density growth. When comparing these gully length dynamics to controlling factors of land use and rainfall, it can be seen in Table 3 that this rapid growth could be related to extreme rainfall events that occurred in 1997 and anomalous rainy periods in 2009-2011. In contrast, in some periods, such as for instance in 1956-1980, 19992001, 2001-2005, and 2007-2009, the gully network underwent several decreases in the drainage density, although in no case was this decrease more than $4 \mathrm{~m} \mathrm{ha}^{-1}$, and can therefore be considered modest. These decreases may be directly related to farming operations in which farmers fill in the upstream gully stretches that are limited in depth and can be considered to be ephemeral gullies.

Figure 10 shows the frequency distribution of headcut growth and infilling of individual gullies for the different periods between 1956 and 2013. Some of the observation periods exhibit a balance between infilling and growing reaches, which leads to a very minor overall change in the total gully network length. During a few distinct intervals however, 1984-1999 and 2009-2011, this balance shifts drastically and results in a fast increase in the gully network's total 


$\begin{array}{ccccc}1956 & 1980 & 1984 & 1999 & 2001 \\ D d=17.2 \mathrm{~m} / \mathrm{ha} & D d=13.5 & D d=18.7 & D d=33.3 & D d=32.1\end{array}$

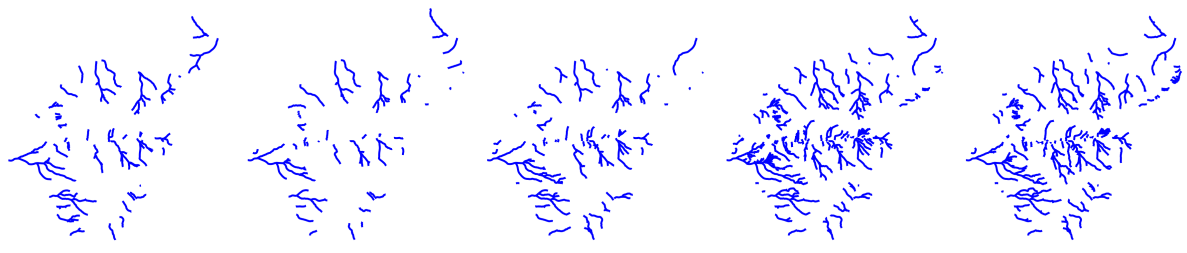

$\begin{array}{ccccc}2005 & 2007 & 2009 & 2011 & 2013 \\ D d=30.4 & D d=31.1 & D d=28.5 & D d=52.1 & D d=53.3\end{array}$

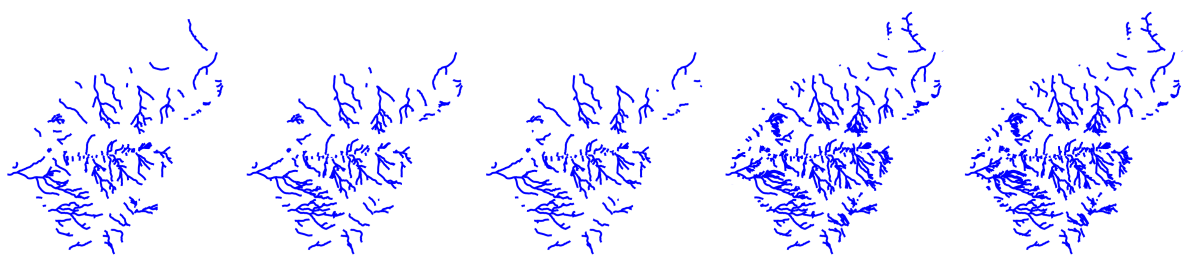

Figure 9. Gully network evolution and drainage density $\left(D_{\mathrm{d}}\right)$, in $\mathrm{m} \mathrm{ha}^{-1}$, at each period.
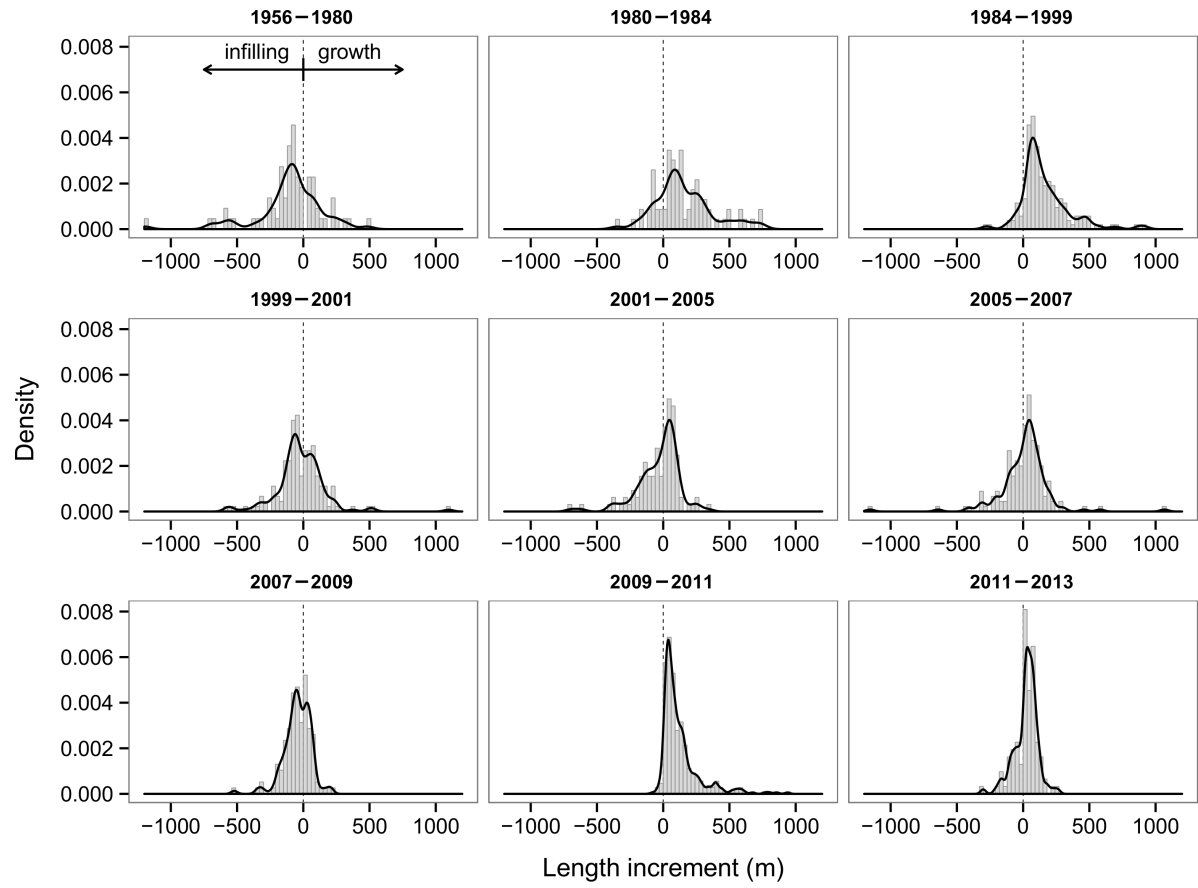

Figure 10. Gully headcut growth or decrease in the different periods between 1956 and 2013.

length, as can be seen in Fig. 11. This can partly be explained by the fact that, in these two periods, infillings are almost negligible (Figs. 10 and 11). However, in Fig. 11, the growth of the gully at the end of those periods (1999 and 2011) is much greater ( 31 and $49 \mathrm{~km}$ ) than those from the other end periods (13 km as the highest value), which clearly shows that gully growth was the dominant process controlling gully dynamics in those periods.
Figure 11 shows how the total length of the gully network tripled from $35.4 \mathrm{~km}$ in 1956 to $109.8 \mathrm{~km}$ in 2013 (Fig. 11). Main enlargement periods were registered in 1980-1984 (10.6 km), 1984-1999 (29.9 km), and 2009-2011 (48.8 km). In contrast, during some other periods, like, for instance, in 1956-1980, 1999-2001, 2001-2005, and 2007-2009, the balance between infilling and growing stretches resulted in a net reduction of the total gully network length. Infilling gully 
Table 4. Kolmogorov-Smirnov tests ( $p$ values) obtained by fitting observed gully widths during different years.

\begin{tabular}{lllllllllll}
\hline Pdf & 1956 & 1980 & 1984 & 1999 & 2001 & 2005 & 2007 & 2009 & 2011 & 2013 \\
\hline Normal & 0.18 & 0.24 & 0.25 & 0.19 & 0.21 & 0.33 & 0.21 & 0.12 & 0.03 & 0.07 \\
Gamma & 0.66 & 0.77 & 0.55 & 0.81 & 0.74 & 0.96 & 0.77 & 0.67 & 0.43 & 0.71 \\
Lognormal & 0.71 & 0.98 & 0.69 & 0.98 & 0.97 & 0.94 & 0.90 & 0.92 & 0.64 & 0.76 \\
Weibull & 0.36 & 0.60 & 0.60 & 0.48 & 0.66 & 0.65 & 0.42 & 0.47 & 0.21 & 0.48 \\
\hline
\end{tabular}

Pdf: probability distribution function.

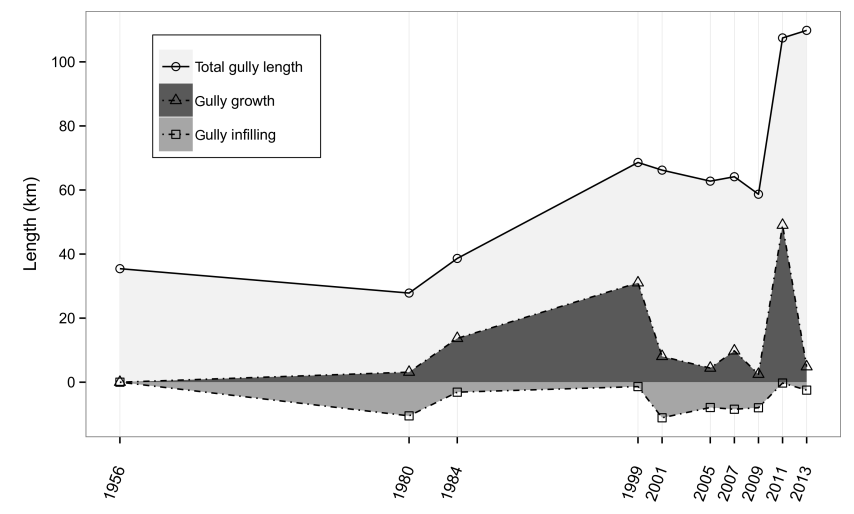

Figure 11. Gully length dynamics in the period 1956-2013.

stretches identified during photointerpretation could be classified into two different types, those made during regular tilling operations at the end of the summer, usually of the order of several tens of metres, and those resulting from land levelling during land use change phases, which may reach some hundreds of metres.

Extraordinary annual rainfalls as well as individual extreme precipitation events seem to be the main factors that can be linked to gully retreat (Table 3). Land use does not seem to be the dominant factor controlling these observed peaks in gully length increase. However, we cannot exclude the possibility of land use change having contributed to the rainfall extremes inducing high peak discharges, because, since 1956, a shift from cereal crops to olive orchards occurred in half of the study area, and was especially intensive from 1984 onward. Young olive trees with limited root systems and small canopies leave an important soil surface bare and give little protection to overland flow or gully headcut advance. However, further analysis should be performed in order to confirm this hypothesis.

\subsection{Gully network width dynamics}

The top width at the representative cross sections, as derived from the orthophoto dataset, experienced continuous widening over time (Fig. 12). While at the beginning of the study period (1956), the maximum top width was close to $12.0 \mathrm{~m}$, this value progressively increased over subsequent years until reaching a maximum value of $59.0 \mathrm{~m}$ in 2013 . The average

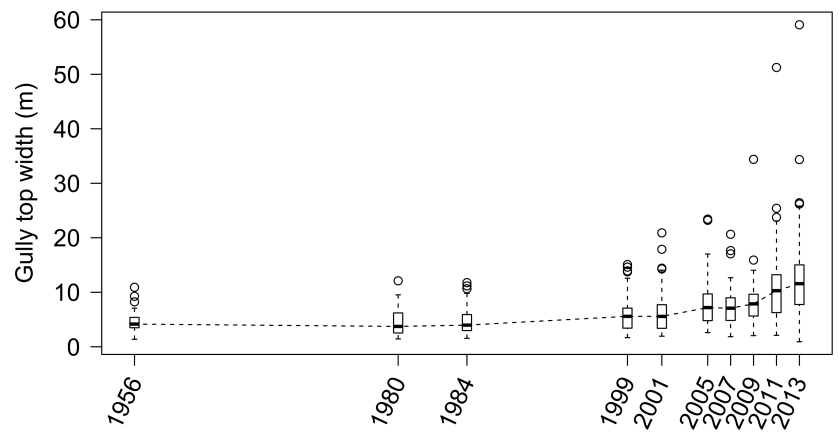

Figure 12. Gully top width dynamics in the period 1956-2013 derived by measuring by photointerpretation. The dashed line indicates the mean; box and whiskers indicate the 25-50 and 5-95\% quantile ranges, respectively.

value increased smoothly from $4.5 \mathrm{~m}$ wide in 1956 to $8.0 \mathrm{~m}$ in 2005, whereas the rate of increase for the period 20052013 clearly got steeper, resulting in a final average width of $13.1 \mathrm{~m}$ in 2013. Although widening could be expected at every time step, average widths derived from the cross sections in $2007(7.7 \mathrm{~m})$ actually experienced a narrowing with respect to those measured in $2005(8.0 \mathrm{~m})$. Since this period (2005-2007) underwent the highest rate of land use change in the series, this reduction in cross section could be explained by the reopening of gullies that had previously been removed by land levelling during a land use shift to olive orchards.

Table 4 summarizes $p$ values obtained by means of the Kolmogorov-Smirnov statistic, which was used to evaluate the suitability of different theoretical probability distributions for fitting the observed top widths. The lognormal distribution showed itself to be the most suitable for almost all the years, with the highest $p$ value of 0.98 in 1980 and 1999 and the lowest $p$ value of 0.64 for 2011, although it was still the best fit for all the distributions tested. These fitted probability distributions were then used to simulate 1000 random widths for each year and a single segment comprising the gully network.

\subsection{Width and depth relationship}

In order to compute the volume of the gully network, depths at the different stretches were derived from the Monte Carlo 


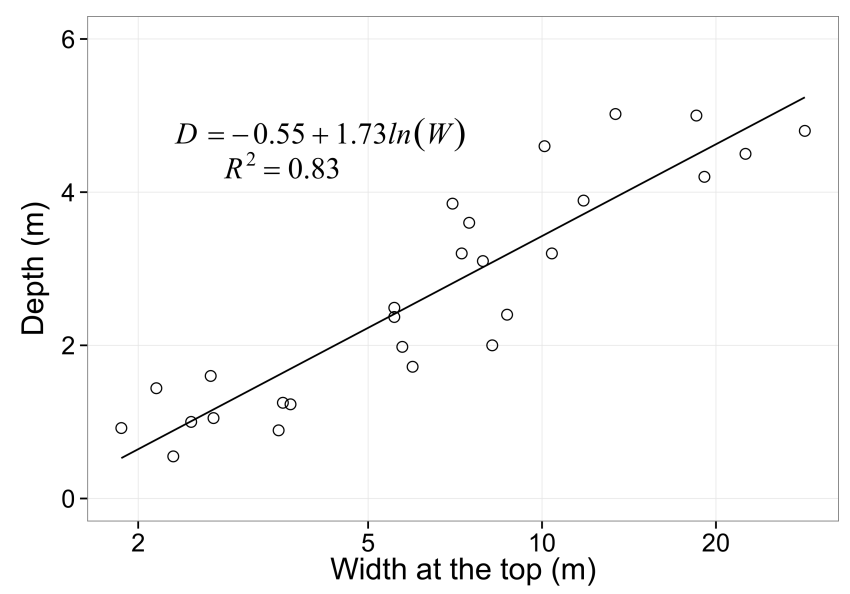

Figure 13. Width-depth relationship derived from field measurements.

simulated widths using a width-depth relation resulting from field work, shown in Fig. 13. A coefficient of determination $R^{2}=0.83$ was obtained from a logarithm-based fitting, with slope, intercept, and their standard deviation, respectively, $1.73 \pm 0.16$ and $0.55 \pm 0.32$. Normal deviates based on those coefficients were used to generate 1000 width and depth pairs.

\subsection{Gully volume dynamics}

Figure 14 presents the final volume evolution, as calculated by means of the Monte Carlo simulation. Gully stretches with a single, observed length were multiplied by the generated width and depth pairs, resulting in 1000 simulated gully network volumes for each stretch and for each period. The average volume in addition to minimum and maximum volumes were then obtained from the set of simulations, showing the growth of the gully in terms of mean eroded volume, as well as a measure of uncertainty, by means of the 5-95\% confidence interval of these inferences, shown in grey. Gully network volume grew from $0.18 \mathrm{~h} \mathrm{~m}^{3}$ in 1956 to $3.24 \mathrm{~h} \mathrm{~m}^{3}$ in 2013. These results show how the original value of the total gully volume has increased 17 times. The main periods of rapid volume growth occurred at the end of the study period, between 2009 and 2013, when the gully volume increased from $0.82 \mathrm{~h} \mathrm{~m}^{3}$ until its final value of $3.24 \mathrm{~h} \mathrm{~m}^{3}$. Moreover, the period 2009-2011 alone accounts for nearly $52 \%$ of the observed growth. Infilling phases were also reflected in the volume evolution curve shown in Fig. 14, such as for instance at the end of the period 1956-1980, when the gully volume decreased until it reached its minimum value $\left(0.15 \mathrm{~h} \mathrm{~m}^{3}\right)$, and in 2007, which shows a $0.015 \mathrm{~h} \mathrm{~m}^{3}$ decrease from the average volume in $2005\left(0.81 \mathrm{~h} \mathrm{~m}^{3}\right)$.

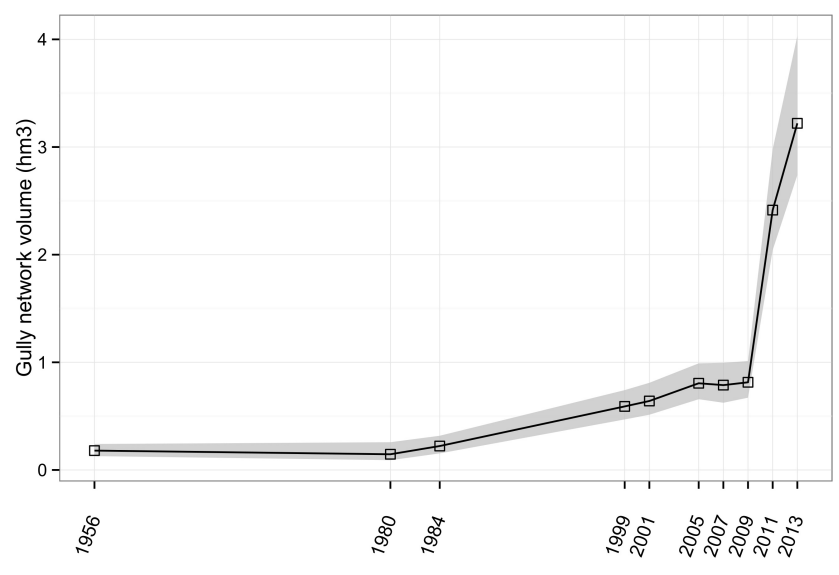

Figure 14. Gully network volume dynamics in the period 19562013 and the uncertainty interval (grey).

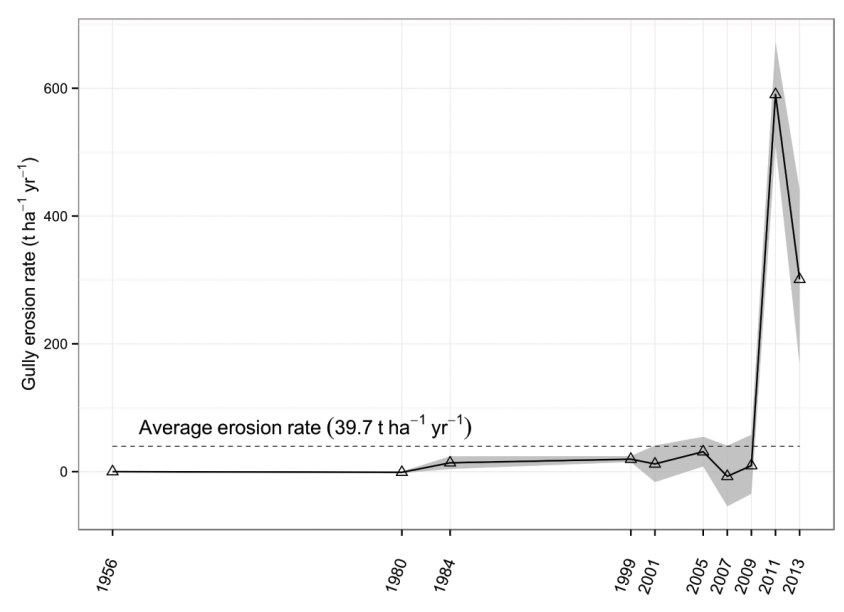

Figure 15. Gully erosion rate in $\mathrm{tha}^{-1} \mathrm{yr}^{-1}$ calculated by the Monte Carlo simulation method, and average erosion rate in the period 1956-2013. The grey area represents the $90 \%$ uncertainty level.

\subsection{Gully erosion rate dynamics}

Dynamics of the gully erosion rate are shown in Fig. 15. The maximum erosion rate was reached in the period 2009-2011, when $591 \mathrm{tha}^{-1} \mathrm{yr}^{-1}$ were lost according to the Monte Carlo results. The minimum erosion rate $\left(-5.21 \mathrm{tha}^{-1} \mathrm{yr}^{-1}\right)$ was recorded in the period 2005-2007. Negative values here reflect the decrease in the gully network volume, and it should therefore be considered an infilling and not an erosion rate. The average erosion rate for the whole study period was $39.7 \mathrm{tha}^{-1} \mathrm{yr}^{-1}$.

\section{Discussion}

The average gully erosion rate of $39.7 \mathrm{tha}^{-1} \mathrm{yr}^{-1}$ for the total catchment area obtained in this study, by means of photointerpretation techniques combined with stochastic meth- 
ods, is of the same order of magnitude as those found in the literature on Mediterranean basins. Oostwoud Wijdenes et al. (2000) reported erosion rates of $1.2 \mathrm{tha}^{-1} \mathrm{yr}^{-1}$ in bank gullies, developing into highly erodible sedimentary deposits in the southeast of Spain, derived by aerial photo analysis over a 38-year period. The highest gully erosion rate of $331 \mathrm{tha}^{-1} \mathrm{yr}^{-1}$ referring to its catchment was found by Martínez-Casasnovas et al. (2003) in large gullies in northeastern Spain from high-resolution DEMs and GIS analysis in a 36-year period. Compared to other erosion processes, the gully erosion rates measured here almost double the average erosion rates for sheet and rill erosion reported for olive orchards in the Mediterranean $\left(23.2 \mathrm{tha}^{-1} \mathrm{yr}^{-1}\right)$ by Gómez et al. (2008). Olive orchards are one of the most important crops in the Mediterranean and are generally considered to be highly affected by sheet and rill erosion. This clearly stresses the importance of adequately considering gully erosion processes when modelling soil losses from water erosion.

Most importantly, the results show a wide variability in gully erosion rates, ranging between -5.21 and $591 \mathrm{tha}^{-1} \mathrm{yr}^{-1}$. This includes periods dominated by infilling and rapid growth, underlining the importance of measuring erosion rates at the finest temporal resolution possible in order to prevent under- and/or over-estimations in sediment production. Such variability is in part explained by the inherent irregularity of the local rainfall regime, which appears to be the main controlling factor for gully erosion at this site. However, land use change has played an important role, intensifying in some cases and masking in other cases gully erosion rates. For instance, in the initial period between 1956 and 1980, the erosion rate gave a negative value. However, given the length of this period and since there were some particular years (i.e. 1961-1962) with extreme rainfall, it is likely that positive gully growth occurred during this period, which was later masked by infilling. This shows that longer periods, such as 1956-1980 and 1984-1999, were subject to a greater uncertainty with respect to the post-1999 period, when a higher temporal resolution was available. Infilling phases could be expected to be followed by those with higher erosion rates. Gordon et al. (2008) obtained the latter from periodically infilled gullies compared to gullies left undisturbed. However, our results do not show that trend. For example, land use change and infilling between 2005 and 2007 were followed by only a moderate gully erosion phase in the 2007-2009 period.

Moreover, the data presented here clearly show that, in Mediterranean areas (Köppen climate type Csa), the gully growth dynamics are different, for instance, to those in temperate oceanic western European areas (Köppen type Cfb). A review of different studies on gully growth over time by Poesen et al. (2006) indicated a rapid initial growth, followed by a stable phase with slow growth for "mature" gullies. Data for this study were from the temperate oceanic $(\mathrm{Cfb})$ loess belt or from lab experiments under constant discharge conditions. In our case, with a high variability in natural rainfall, even after several decades, intense growth phases were observed. This observation is not unique since, in another environment, Shellberg et al. (2016) have detected an almost continuous increasing trend in the gullies of the Mitchell River in Queensland. As stated before, these could mainly be attributed to an increase in the gully's cross sections, and less to a gully headcut retreat. Therefore, models such as CHILD or REGEM, which have been applied with success to gully modelling, but focus mainly on headcut activities, would probably not yield good results in this case.

From a wider geomorphological perspective, other phenomena such as lowering of the base level and incision of the river bed could be suggested as being a cause of the progressive increase in the erosion rate. During the Quaternary, the main Guadalquivir River was at an incision stage due to its base level fall. However, this incision has been slow, as demonstrated by Uribelarrea and Benito (2008), who found evidence of only a $1.2 \mathrm{~m}$ incision over the last 500 years. In any case, since the 1950s-1960s, when many dams were constructed, the Guadalquivir has been a highly regulated river. Such dams are known to have a downstream incision effect due to removal of sediment load and an upstream aggradation effect. With respect to our study area, there are no upstream but only downstream dams. Therefore, it is surmised that the influence of the incision stage has been artificially limited in this catchment since the 1950s and that the observed changes in the gully network can be fully attributed to upstream changes in the rainfall or land use regimes.

Gully erosion rates computed between the start and the end of the study period would incur gross underestimation. Erosion rates between 1956 and 2009 were under the average (39.7 $\left.\mathrm{tha}^{-1} \mathrm{yr}^{-1}\right)$, while the last period (2009-2013) accounted for around $52 \%$ of the gully volume growth, reaching a peak value of $591 \mathrm{tha}^{-1} \mathrm{yr}^{-1}$ in the period 2009-2011. Nevertheless, these observations are in accordance with other studies in the Mediterranean. Gully erosion rates after some extreme rainfall events in the Mediterranean basin has been reported as occasionally reaching $207 \mathrm{tha}^{-1}$ (MartínezCasasnovas et al., 2002). In a review of the western Mediterranean basin, González-Hidalgo et al. (2007) found that, on average, the three largest daily events per year accounted for more than $50 \%$ of the total sediment exported from the basin. Nevertheless Wolman and Miller (1960) observed the relevance of relatively frequent events of moderate magnitude. Gioia et al. (2008) stressed the importance of different runoff thresholds to explain flood occurrence in the Mediterranean areas. Ordinary flows are produced when rainfall rate exceeds the infiltration rate of the soil in a small area, a typical case of Hortonian runoff generation, or Hortonian threshold, while what Gioia et al. (2008) denoted outlier events occurred when the water of almost continuous rain spells surpassed the storage capacity of the soil in a large area of the catchments or Dunnean threshold. The so-called time compression of Mediterranean climate with respect to soil erosion is therefore very high, as is demonstrated by the data 
from this study. Our data seem to indicate that land use did not play a dominant role, although we cannot exclude land use changes to olives and soil management having lowered the land's resilience towards gully incision.

The Monte Carlo stochastic modelling performed allows one to verify that while gully length dynamics (Fig. 11) could explain some of the rapid increases in the volume and erosion rate computed, widening processes (Fig. 12) determine the shape of the volume curve (Fig. 14), pointing to the importance of that parameter in the computed volume as opposed, in this particular case, to that suggested by other authors, that, for other areas and climates, the leading controlling parameter is gully length (Nachtergaele and Poesen, 1999). This observation will lead to future field work and modelling efforts, which should not only consider gully headcut advance, but also the mechanisms of gully sidewall collapse and erosion. Possibly a very important factor here, in order to control gully growth, is the possible effect of roots on stabilizing the gully walls (De Baets et al., 2008).

The main advantage of the new method described here is that by means of Monte Carlo simulation, an estimation of the uncertainty associated with the measurement of gully erosion volume is generated. This is especially relevant when suitable knowledge of erosion dynamics is required, and management systems need to be evaluated or compared. Although more field measurements of gully sections would be advantageous in order to reduce uncertainty, time and money spent on ground truthing would increase accordingly. However, the high $p$ values of $0.64-0.98$ obtained here for the fit between the theoretical probability distribution function and the experimental data suggest satisfactory results can be obtained, even with a limited field sample. Moreover, Istanbulluoglu et al. (2002) also successfully used a Monte Carlo approach to estimate gully incision locations using a similar amount of field data.

\section{Conclusions}

A new method was presented to evaluate gully growth over decadal timescales, combining air photointerpretation with a stochastic approach through Monte Carlo modelling for the channel section parameters. This method constitutes a reliable procedure to determine gully network dynamics over time. Uncertainty ranges obtained in the simulation provide an unprecedented view of the gully network dynamics useful from a management perspective. While highly variable, the observed erosion rates were in accordance with previous studies in Mediterranean basins. The fluctuations in erosion rates were mainly attributed to the variability in rainfall regime variations, likely to have been exacerbated by land use changes, although further research on runoff, gully headcut retreat rates, and sidewall dynamics should be made at this last point.
Simple interpolation between the start and end dates would highly underestimate gully contributions during certain years, as could be verified when comparing the average erosion rate $\left(39.7 \mathrm{tha}^{-1} \mathrm{yr}^{-1}\right)$ with sporadic erosion rates at the end of the study period to a maximum of $591 \mathrm{t} \mathrm{ha}^{-1} \mathrm{yr}^{-1}$. Gully erosion is confirmed to being an important sediment generation process in Mediterranean basins. Average erosion rates from gullies in the study period almost double their values for similar locations and conditions obtained for rill and sheet erosion.

Further studies with more field data are needed to improve the estimations of the contribution of the different land uses to gully growth. Implementation of physically based models of gully retreat rates and sidewall collapse as well as more field measurements and interviews with local farmers on soil management practice could contribute to a better understanding of the elongation processes and predict gully erosion under different scenarios, including the effect of added root cohesion to sidewall stability or gully headcut protection.

\section{Data availability}

Maps of the Land Use and Vegetation Cover of Andalusia for the years 1956, 1980, 1984, 1999, 2003, and 2007, and orthophotos can be accessed through the Red de Información Ambiental de Andalucía (REDIAM) repository website (http://laboratoriorediam.cica.es/ ContenidosRediam/Matriz.do). Rainfall data and data on gully erosion are currently available by contacting the corresponding author. These data are not available through a data repository.

Acknowledgements. This research was funded under research project AGL2012-40128-C03-02. We thank the anonymous referees for their valuable comments on the discussion paper.

Edited by: N. Romano

Reviewed by: four anonymous referees

\section{References}

Amundson, R., Berhe, A. A., Hopmans, J. W., Olson, C., Sztein, A. E., and Sparks, D. L.: Soil and human security in the $21^{\text {st }}$ century, Science, 348, 6235, doi:10.1126/science.1261071, 2015.

Campo-Bescós, M. A., Flores-Cervantes, J. H., Bras, R. L., Casalí, J., and Giráldez, J. V.: Evaluation of a gully headcut retreat model using multitemporal aerial photographs and digital elevation models, J. Geophys. Res.-Ea. Surf., 118, 2159-2173, doi:10.1002/jgrf.20147, 2013.

Castillo, C.: Metodología de medida de la erosión por cárcavas y modelado de su control mediante diques de retención, $\mathrm{PhD}$ diss., University of Córdoba, Dept. of Rural Engineering, Córdoba, http://hdl.handle.net/10396/8521 (last access: 1 December 2015), 2012. 
Castillo, C., Pérez, R., James, M. R., Quinton, J. N., Taguas, E. V., and Gómez, J. A.: Comparing the accuracy of several field methods for measuring gully erosion, Soil Sci. Soc. Am. J., 76, 1319-1332, doi:10.2136/sssaj2011.0390, 2012.

Castillo, C., James, M. R., Redel-Macías, M. D., Pérez, R., and Gómez, J. A.: SF3M software: 3-D photo-reconstruction for nonexpert users and its application to a gully network, SOIL, 1, 583594, doi:10.5194/soil-1-583-2015, 2015.

Dabney, S., Vieira, D., Yoder, D., Langendoen, E., Wells, R., and Ursic, M.: Spatially distributed sheet, rill, and ephemeral gully Erosion, J. Hydrol. Eng.-ASCE, 20, C4014009, doi:10.1061/(ASCE)HE.1943-5584.0001120, 2014.

De Baets, S., Poesen, J., Reubens, B., Wemans, K., De Baerdemaeker, J., and Muys, B.: Root tensile strength and root distribution of typical Mediterranean plant species and their contribution to soil shear strength, Plant Soil, 305, 207-226, doi:10.1007/s11104-008-9553-0, 2008.

Devauchelle, O., Petroff, A. P., Seybold, H. F., and Rothman, D. H.: Ramification of stream networks, P. Natl. Acad. Sci. USA, 109, 20832-20836, doi:10.1073/pnas.1215218109, 2012.

Dotterweich, M.: The history of human-induced soil erosion: Geomorphic legacies, early descriptions and research, and the development of soil conservation: A global synopsis, Geomorphology, 201, 1-34, doi:10.1016/j.geomorph.2013.07.021, 2013.

Flores-Cervantes, J. H., Istanbulluoglu, E., and Bras, R. L.: Development of gullies on the landscape: A model of headcut retreat resulting from plunge pool erosion, J. Geophys. Res.-Ea. Surf., 111, F01010, doi:10.1029/2004JF000226, 2006.

Frankl, A., Nyssen, J., De Dapper, M., Haile, M., Deckers, J., and Poesen, J.: Trends in gully erosion as evidenced from repeat photography (North Ethiopia), Landf. Anal., 17, 47-50, 2011.

Frankl, A., Poesen, J., Haile, M., Deckers, J., and Nyssen, J.: Quantifying long-term changes in gully networks and volumes in dryland environments: The case of Northern Ethiopia, Geomorphology, 201, 254-263, doi:10.1016/j.geomorph.2013.06.025, 2013.

Frankl, A., Stal, C., Abraha, A., Nyssen, J., Rieke-Zapp, D., De Wulff, A., and Poesen, J.: Detailed recording of gully morphology in 3D through image-based modelling, Catena, 127, 92101, doi:10.1016/j.catena.2014.12.016, 2015.

Gioia, A., Iacobellis, V., Manfreda, S., and Fiorentino, M.: Runoff thresholds in derived flood frequenncy distributions, Hydrol. Earth Syst. Sci., 12, 1295-1307, doi:10.5194/hess-12-12952008, 2008.

Gómez, J. A., Giráldez, J. V. and Vanwalleghem, T.: Comments on "Is soil erosion in olive groves as bad as often claimed?" by L. Fleskens and L. Stroosnijder, Geoderma, 147, 93-95, doi:10.1016/j.geoderma.2008.07.006, 2008.

Gómez-Gutiérrez, A., Schnabel, S., Berenguer-Sempere, F., Lavado-Contador, F., and Rubio-Delgado, J.: Using 3D photoreconstruction methods to estimate gully headcut erosion, Catena, 120, 91-101, doi:10.1016/j.catena.2014.04.004, 2014.

González-Hidalgo, J. C., Peña-Monné, J. L., and de Luis, M.: A review of daily soil erosion in Western Mediterranean areas, Catena, 71, 193-199, doi:10.1016/j.catena.2007.03.005, 2007.

Gordon, L. M., Bennett, S. J., Bingner, R. L., Theurer, F. D., and Alonso, C. V.: Simulating ephemeral gully erosion in AnnAGNPS, T. ASABE, 50, 857-866, 2007.

Gordon, L. M., Bennett, S. J., Alonso, C. V., and Bingner, R. L.: Modeling long-term soil losses on agricultural fields due to ephemeral gully erosion, J. Soil Water Conserv., 63, 173-181, doi:10.2489/jswc.63.4.173, 2008.

Istanbulluoglu, E., Tarboton, D. G., Park, R. T., and Luce, C.: A probabilistic approach for channel initiation, Water Resour. Res., 38, 61-1-61-14, doi:10.1029/2001WR000782, 2002.

Kirkby, M. J. and Bracken, L. J.: Gully processes and gully dynamics, Earth Surf. Proc. Land., 34, 1841-1851, doi:10.1002/esp.1866, 2009.

Leopold, A.: Pioneers and gullies, in: The River of the Mother of God and other essays, edited by: Fladder, S. L. and Callicott, J. B., University of Wisconsin Press, Madison, 106-113, 1991.

Martínez-Casanovas, J. A.: A spatial information technology approach for the mapping and quantification of gully erosion, in: Int. Symp. on Gully Erosion under Global Change, Book of Abstracts, K. U. Leuven, Leuven, p. 89, 2000.

Martínez-Casasnovas, J. A., Ramos, M. C., and Ribes-Dasi, M.: Soil erosion caused by extreme rainfall events: mapping and quantification in agricultural plots from very detailed digital elevation models, Geoderma, 105, 125-140, 2002.

Martínez-Casasnovas, J. A., Antón-Fernández, C., and Ramos, M. C.: Sediment production in large gullies of the Mediterranean area (NE Spain) from high-resolution digital elevation models and geographical information systems analysis, Earth Surf. Proc. Land., 28, 443-456, doi:10.1002/esp.451, 2003.

Marzolff, I. and Poesen, J.: The potential of 3D gully monitoring with GIS using high-resolution aerial photography and a digital photo-grammetry system, Geomorphology, 111, 48-60, doi:10.1016/j.geomorph.2008.05.047, 2011.

Momm, H. G., Bingner, R. L., Wells, R. R., and Dabney, S.: Methods for gully characterization in agricultural croplands using ground-based light detection and ranging, in: Sediment transport - Flow and morphological processes, chap. 5, edited by: Bhuiyan, F., InTech, Rijeka, Croatia, 2011.

Momm, H. G., Bingner, R. L., Wells, R. R., and Wilcox, D.: AGNPS GIS-based tool for watershed-scale identification and mapping of cropland potential ephemeral gullies, Appl. Eng. Agr., 28, 1-13, 2012.

Nacthergaele, J. and Poesen, J.: Assessment of soil losses by ephemeral gully erosion using high-altitude (stereo) aerial photographs, Earth Surf. Proc. Land., 24, 693-706, 1999.

Nyssen, J., Poesen, J., Veyret-Picot, M., Moeyersons, J., Haile, M., Deckers, J., Dewit, J., Naudts, J., Teka, K., and Govers, G.: Assessment of gully erosion rates through interviews and measurements: a case study from northern Ethiopia, Earth Surf. Proc. Land., 31, 167-185, doi:10.1002/esp.1317, 2006.

Oostwoud Wijdenes, D. J., Poesen, J., Vandekerckhove, L., and Ghesquiere, M.: Spatial distribution of gully head activity and sediment supply along an ephemeral channel in a Mediterranean environment, Catena, 39, 147-167, 2000.

Panagos, P., Borrelli, P., Poesen, J., Ballabio, C., Lugato, E., Meusburger, K., Montanarella, L., and Alewell, C.: The new assessment of soil loss by water erosion in Europe, Environ. Sci. Policy, 54, 438-447, doi:10.1016/j.envsci.2015.08.012, 2015.

Peter, K. D., d'Oleire-Oltmanns, S., Ries, J. B., Marzolff, I., and Hssaine, A. A.: Soil erosion in gully catchments affected by landlevelling measures in the Souss Basin, Morocco, analysed by rainfall simulation and UAV remote sensing data, Catena, 113, 24-40, doi:10.1016/j.catena.2013.09.004, 2014. 
Poesen, J., Vandekerckhove, L., Nachtergaele, J., Wijdenes, D. O., Verstraeten, G., and Van Wesemael, B.: Gully erosion in dryland environments, in: Dryland rivers: Hydrology and Geomorphology of semi-arid channels, chap. 8, edited by: Bull, L. J. and Kirkby, M. J., John Wiley \& Son, Chichester, UK, 2002.

Poesen, J., Vanwalleghem, T., de Vente, J., Knapen, A., Verstraeten, G., and Martínez-Casasnovas, J. A.: Gully erosion in Europe, in: Soil erosion in Europe, chap. 39, edited by: Boardman, J. and Poesen, J., John Wiley \& Son, Chichester, UK, 2006.

Quinton, J. N., Govers, G., Van Oost, K., and Bardgett, R. D.: The impact of agricultural soil erosion on biogeochemical cycling, Nat. Geosci, 3, 311-314, doi:10.1038/ngeo838, 2010.

Regnier, P., Friedlingstein, P., Ciais, P., Mackenzie, F. T., Gruber, N., Janssens, I. A., Laruelle, G. G., Lauerwald, R., Luyssaert, S., Andersson, A. J., Arndt, S., Arnosti, C., Borges, A. V., Dale, A. W., Gallego-Sala, A., Godderis, Y., Goossens, N., Hartmann, J., Heinze, C., Ilyina, T., Joos, F., LaRowe, D. E., Leifeld, J., Meysman, F. J. R., Munhoven, G., Raymond, P. A., Spahni, R., Suntharalingam, P., and Thullner, M.: Anthropogenic perturbation of the carbon fluxes from land to ocean, Nat. Geosci., 6, 597-607, 2013.

Renard, K. G., Foster, G. R., Weesies, G. A., McCool, D. K., and Yoder, D. C.: Predicting soil erosion by water: a guide to conservation planning with the Revised Universal Soil Loss Equation (RUSLE), USDA Agr. Hbk. 703, USDA, Washington, D.C., 1997.

Rengers, F. K. and Tucker, G. E.: Analysis and modeling of gully headcut dynamics, North American high plains, J. Geophys. Res.-Ea. Surf., 119, 983-1003, doi:10.1002/2013JF002962, 2014.

Saxton, N. E., Olley, J. M., Smith, S., Ward, D. P., and Rose, C. W.: Gully erosion in sub-tropical sout-h-east Queensland, Australia, Geomorphology, 173-174, 80-87, doi:10.1016/j.geomorph.2012.05.030, 2012.

Shellberg, J. G., Spencer, J., Brooks, A. P., and Pietsch, T. J.: Degradation of the Mitchell River fluvialmegafan by alluvial gully erosion increased by post-European land use change, Queensland, Australia, Geomorphology, 266, 105-120, doi:10.1016/j.geomorph.2016.04.021, 2016.
Taguas, E. V., Yuan, Y., Bingner, R. L., and Gómez, J. A.: Modeling the contribution of ephemeral gully erosion under different soil managements: A case study in an olive orchard microcatchment using the AnnAGNPS model, Catena, 98, 1-16, doi:10.1016/j.catena.2012.06.002, 2012.

Tebebu, T. Y., Abiy, A. Z., Zegeye, A. D., Dahlke, H. E., Easton, Z. M., Tilahun, S. A., Collick, A. S., Kidnau, S., Moges, S., Dadgari, F., and Steenhuis, T. S.: Surface and subsurface flow effect on permanent gully formation and upland erosion near Lake Tana in the northern highlands of Ethiopia, Hydrol. Earth Syst. Sci., 14, 2207-2217, doi:10.5194/hess-14-2207-2010, 2010.

Uribelarrea, D. and Benito, G.: Fluvial changes of the Guadalquivir river during the Holocene in Córdoba (Southern Spain), Geomorphology, 100, 14-31, doi:10.1016/j.geomorph.2007.04.037, 2008.

Van Oost, K., Quine, T. A., Govers, G., De Gryze, S., Six, J., Harden, J. W., Ritchie, J. C., McCarty, G. W., Heckrath, G., Kosmas, C., Giráldez, J. V., da Silva, J. R. M., and Merckx, R.: The Impact of Agricultural Soil Erosion on the Global Carbon Cycle, Science, 318, 626-629, doi:10.1126/science.1145724, 2007.

Vanwalleghem, T., Bork, H. R., Poesen, J., Schmidtchen, G., Dotterweich, M., Nachtergaele, J., Bork, H., Deckers, J., Brüsch, B., Bungeneers, J., and De Bie, M.: Rapid development and infilling of a buried gully under cropland, central Belgium, Catena, 63, 221-243, doi:10.1016/j.catena.2005.06.005, 2005.

Vanwalleghem, T., Bork, H. R., Poesen, J., Dotterweich, M., Schmidtchen, G., Deckers, J., Scheers, S., and Martens, M. Prehistoric and Roman gullying in the European loess belt: a case study from central Belgium, Holocene, 16, 393-401, doi:10.1191/0959683606hl935rp, 2006.

Vinci, A., Todisco, F., and Mannocchi, F.: Calibration of manual measurements of rills using Terrestrial Laser Scanning, Catena, 140, 164-168, doi:10.1016/j.catena.2016.01.026, 2016.

Wischmeier, W. H. and Smith, D. D.: Predicting rainfall erosion losses - A guide to conservation planning, USDA Ag. Hbk. 537, USDA, Washington, D.C., 1978.

Wolman, M. G. and Miller, J. T.: Magnitude and frequency of forces in geomorphic processes, J. Geol., 60, 54-74, 1960. 